\title{
ADAPTASI TEKNOLOGI DI RUMAH ADAT SUMBA
}

\author{
M.I. Ririk Winandari* \\ Jurusan Arsitektur - Universitas Trisakti, Jl. Kyai Tapa No.1 Grogol, Jakarta Barat \\ *ririkwinandari@yahoo.com
}

\begin{abstract}
ABSTRAK
Pulau sumba memiliki beberapa kampung adat yang masih dan akan terus dipertahankan di masa depan. Masing-masing kampung adat memiliki karakter arsitektur khas, sebuah representasi arsitektur megalitik di bagian Timur nusantara, yang tidak dapat dijumpai di tempat lain. Kekhasan tersebut merupakan bentukan fisik sebuah proses panjang kegiatan dan budaya masyarakat setempat yang juga dipengaruhi oleh faktor ekonomi, bahkan politik penguasa. Keinginan untuk mempertahankan kekhasan inilah yang menjadi kekuatan utama konservasi rumah adat Sumba.

Pada dasarnya, konservasi merupakan upaya yang dilakukan untuk melestarikan bangunan, mengefisienkan penggunaan serta mengatur arah perkembangan di masa mendatang. Di masa kini, upaya tersebut harus didukung oleh perkembangan teknologi. Tanpa dukungan teknologi, bisa dibayangkan ratusan kayu yang harus ditebang, ratusan kubik batu cadas tepian pantai yang harus dipindahkan, dan ratusan alang-alang yang harus ditanam. Dengan kata lain, penggunaan teknologi serta alternatif material sangat diperlukan untuk mempermudah pelestarian bangunan dan lingkungan. Tentunya, penggunaan teknologi tersebut harus berada dalam koridor pelestarian bangunan dan lingkungan. Paper ini akan memaparkan mengenai bantuan teknologi dalam proses kesinambungan budaya dan fisik bangunan rumah adat Sumba.
\end{abstract}

Keywords - Konservasi, Rumah adat Sumba, Teknolog

\section{RUMAH ADAT SUMBA}

Rumah adat bagi masyarakat Sumba merupakan sebuah rumah yang digunakan untuk melaksanakan ritual budaya[7]. Ritual yang dilakukan oleh setiap kabizu/ klan/ sub suku/ kelompok kekerabatan di dalam rumah adatnya masing-masing. Rumah tersebut memiliki fungsi utama sebagai tempat pelaksanaan ritual budaya, tidak hanya sekedar sebagai tempat hunian. Di setiap rumah adat selalu terdapat ruang Marapu, sebuah ruang yang dikhususkan untuk menghormati leluhur dan menyimpan benda yang dikeramatkan. Ruang ini pulalah pusat orientasi semua kegiatan penghuninya terutama yang berkaitan dengan budaya. Umumnya, penghuni tetap rumah adat adalah keluarga anak lelaki tertua di dalam kabizunya (kepala kabizu).

Rumah adat beberapa klan berada dalam sebuah kampung adat yang dalam bahasa setempat disebut dengan Parangu/paraingu/parona. Kampung adat tersebut terbentuk berdasarkan pengelompokkan suku. Namun terkadang dijumpai 2 suku dalam sebuah kampung adat seperti di Kampung Tarung. Di Pulau Sumba sendiri, terdapat sekitar 26 suku yang tersebar di beberapa kampung adat di seluruh Pulau Sumba[4]. 


\section{KONSTRUKSI RUMAH ADAT}

\section{SUMBA}

Bangunan rumah adat Sumba terdiri dari 3 bagian utama yaitu atap/uma deta, induk rumah/bei uma, dan kolong/kali kambunga[5]. Ketinggian atap yang hampir tiga kali tinggi badan bangunan menjadikan atap sebagai bagian yang mendominasi. Hal ini pula yang menyebabkan atap tersebut diistilahkan dengan sebutan atap menara. Konstruksi atap berupa atap panggung yaitu atap dengan bahan kayu sebagai struktur utama dan bambu sebagai kasau[3]. Penutup atap terbuat dari rangkaian ikatan alang-alang yang ditumpuk mulai dari bagian bawah sampai ke atas atap. Bagian induk rumah terdiri dari kolom dan dinding. Konstruksi bangunan menggunakan sistem rangka dengan 4 kolom utama sebagai penopang beban bangunan.

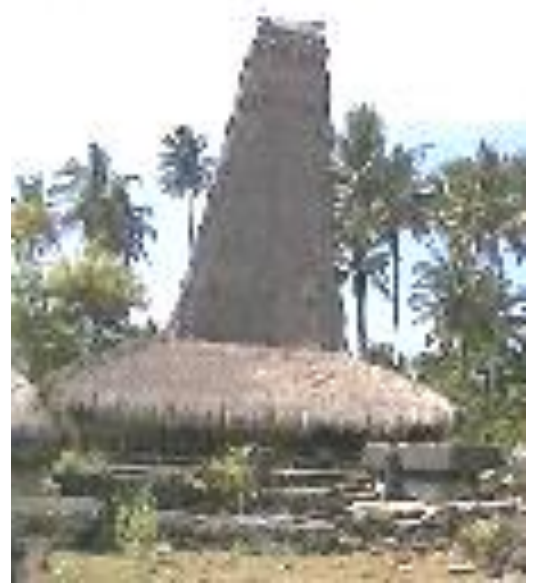

Gambar 1. Tiga bagian utama rumah adat Sumba terdiri dari atap, induk rumah dan kolong.
Keempat kolom tersebut diistilahkan dengan kambaniru ludungu atau tiang agung[1]. Keempatnya berdiri di atas umpak yang terbuat dari batu cadas. Di bagian atas kolom terdapat simpai (bulatan kayu pipih) yang berfungsi sebagai penghambat jalur hewan (tikus) sekaligus sebagai tempat penyimpanan barang berharga. Dinding rumah terbuat dari rangkaian bambu utuh yang disusun horisontal. Sambungan antar bambu diikat dengan tali akar pohon dan dijepit oleh 2 buah bambu vertikal. Bagian kolong rumah adat terdiri dari pondasi serta kolong rumah. Bagian ini berfungsi sebagai tempat memelihara hewan (kandang) seperti ayam, bebek, kambing, bahkan babi.

Seluruh material konstruksi rumah adat Sumba seperti kolom sampai penutup atap berasal dari alam. Setiap material digunakan sebagai bahan konstruksi secara utuh tanpa proses pembelahan. Sistem sambungan konstruksi/ pengikat material menggunakan sistem pasak dan diperkuat dengan ikatan tali yang berasal dari akar pohon hutan yang menggantung (kahikara).

Jumlah material alam yang dibutuhkan dalam membangun sebuah rumah adat sangatlah tinggi. Sebuah rumah adat sumba memerlukan minimal 4 buah pohon utuh berdiameter $50-80 \mathrm{~cm}$ sebagai tiang utama dan puluhan kayu utuh berdiameter kurang dari $50 \mathrm{~cm}$ sebagai penunjang struktur atap dan lantai panggung. Ratusan batang bambu utuh digunakan sebagai bahan pembuat kasau, pengisi dinding, dan penutup lantai rumah. Puluhan bahkan ratusan ribu 
alang-alang sebagai penutup atap serta ribuan akar pohon yang menggantung sebagai tali pengikat.

Proses pembangunan rumah adat dilakukan dengan ritual tertentu. Pembangunan dilakukan secara bergotong royong oleh penghuni kampung. Penarikan kayu sebagai bahan pembuat kolom serta batu cadas sebagai pondasi yang berasal dari hutan atau pinggir laut menggunakan ritual yang disertai pemotongan hewan kurban. Khusus penarikan batu cadas, setiap 1 $\mathrm{km}$ tarikan batu, dilakukan penyembelihan seekor hewan kurban. Dilihat dari lokasi beberapa kampung adat yang berada di atas bukit serta jauh dari laut, bisa dibayangkan berapa jumlah hewan yang harus dikorbankan, bisa puuhan bahkan ratusan. Namun demikian justru hal seperti ini yang menjadikan proses pembangunan rumah adat Sumba menarik terutama bagi wisatawan.

\section{KONSERVASI DAN PERKEMBANGAN TEKNOLOGI}

Konservasi merupakan metode yang dilakukan untuk memperkuat karakter unik suatu lingkungan dan masyarakatnya[2]. Sebuah metode yang dilakukan dalam upaya melestarikan bangunan, mengefisienkan penggunaan serta mengatur arah perkembangannya di masa mendatang. Dalam konteks rumah adat Sumba, karakter unik lingkungan dapat tetap terjaga karena didukung oleh kekuatan adat dan kesetiaan masyarakat terhadap budayanya. Meskipun demikian, perubahan ekonomi, sosial, serta ketersediaan material di bumi
Sumba mulai mempengaruhi kelangsungan budaya dan fisik rumah adat.

Di Tahun 2002, ditemukan beberapa rumah adat yang mulai roboh karena tiang yang termakan rayap atau rusaknya atap alang-alang. Bahkan beberapa kampung adat di Sumba Barat maupun Sumba Timur telah hilang tanpa bekas. Di tempat lain, beberapa bangunan rumah adat yang telah dan sedang direnovasi telah menggunakan material serta konstruksi yang berbeda dengan mempertahankan bentuk fisik bangunan. Beberapa rumah adat mulai menggunakan seng sebagai bahan penutup atap, paku sebagai pengganti ikatan tali yang terbuat dari akar pohon serta penyekatan ruang di dalam rumah adat[6]. Kondisi ini disebabkan karena tingginya kebutuhan akan material alam sementara ketersediaan berkurang, serta keterbatasan dana pemilik rumah adat.

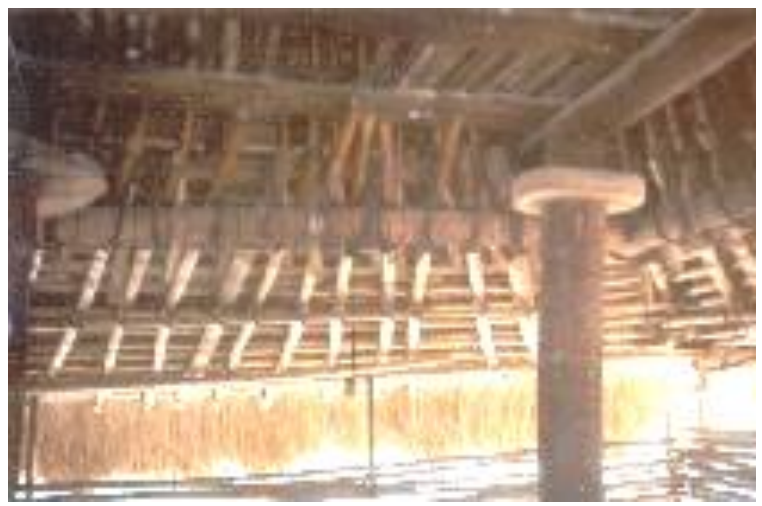

Gambar 2. Konstruksi atap panggung (kayu sebagai struktur utama dan bambu sebagai kasau), sistem rangka, serta simpai pada rumah adat Sumba. 


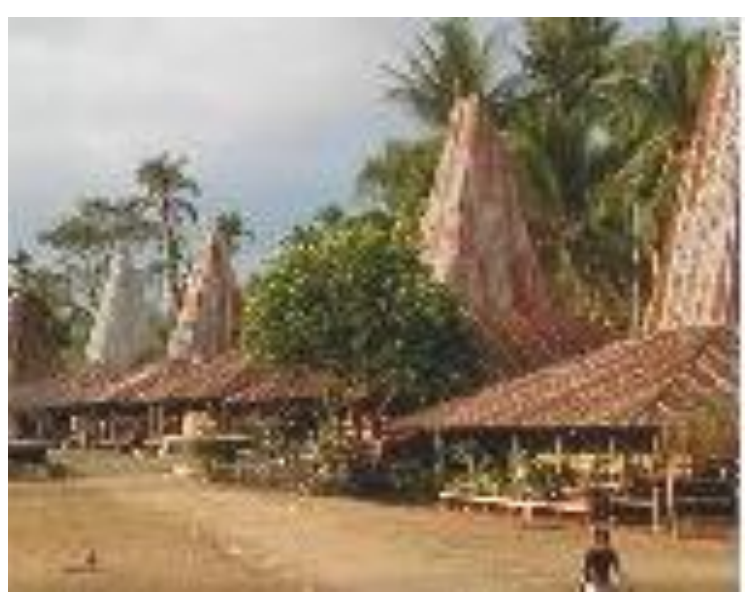

Gambar 3. Beberapa rumah adat menggunakan seng sebagai bahan penutup atap pengganti alang-alang.

Di masa lalu, alang-alang, akar pohon, pohon, dan bambu dapat dengan mudah ditemukan di semua wilayah Pulau Sumba. Saat ini, pasokan bahan-bahan tersebut jauh dari mencukupi. Hal ini disebabkan adanya peningkatan kebutuhan akibat pembangunan, perbaikan rumah adat yang rusak, berkurangnya jumlah pohon dan bambu di hutan, serta serangan rumput liar yang mematikan bibit alang-alang.

Upaya konservasi yang dilakukan untuk menjaga kelestarian rumah adat Sumba dapat dilakukan dengan mempertahankan bentuk fisik bangunan. Untuk itu, diperlukan bantuan teknologi dalam menjembatani kekurangan yang diakibatkan oleh keterbatasan material alam. Material hasil teknologi seperti seng, paku, balok kayu, papan, semen, bahkan beton bertulang dapat digunakan untuk mengganti atau mengurangi penggunaan material seperti alang-alang, akar pohon, bambu, pohon, dan batu cadas. Penggunaan material tersebut jauh lebih hemat, praktis, mudah dan cepat pelaksanaannya dibandingkan dengan material alam.

Beton bertulang pengganti batu cadas sebagai umpak/ pondasi banyak digunakan di kampung Kabonduk, Tarung, dan Rindi. Bentuk umpak tetap dibuat menyerupai batu cadas. Balok kayu pengganti pohon utuh digunakan sebagai penunjang struktur lantai dan atap. Bilah-bilah papan kayu pengganti bambu utuh digunakan sebagai dinding dan lantai bangunan. Bagi warga setempat, penggunaan papan sangat membantu kualitas tidur mereka karena selama ini mereka tidur di atas susunan bambu utuh. Konstruksi ikatan antara balok, papan, dan bambu menggunakan balok gapit dan paku. Satu hal yang pasti tidak akan pernah dilakukan warga dalam pembangunan rumah adat Sumba ataupun rumah biasa adalah penggunaan ijuk sebagai pengganti tali akar pohon. Dalam budaya Sumba, ijuk merupakan simbol rambut manusia. Ikatan ijuk di dalam rumah memberi arti bahwa penghuni berada dalam bayang-bayang kegelapan, sesuatu yang berkaitan dengan kematian.

Rumah adat Sumba sesungguhnya tidak mengenal adanya daun pintu dan jendela. Pintu rumah merupakan bukaan dinding yang berada di depan teras atau tangga. Jendela bahkan tidak dikenal sama sekali. Pada masa lalu, dinding rumah adat hanyalah pembantas berupa susunan bambu setinggi $\pm 50 \mathrm{~cm}$ dari lantai rumah. Perjalanan waktu serta kebutuhan 
penghuni akan privasi di dalam rumah menyebabkan munculnya dinding yang menutup hingga ke langitlangit rumah. Konsekuensi dari penutupan dinding tersebut adalah adanya bukaan jendela sebagai jawaban atas perlunya cahaya dan udara di dalam rumah.

Perubahan ekonomi dan pekerjaan juga menyebabkan terjadinya perubahan dalam pelaksanaan pekerjaan. Sebagian penghuni rumah adat Sumba saat ini bekerja sebagai karyawan maupun pedagang. Waktu mereka yang tersedia untuk membangun atau memperbaiki sendiri rumahnya tentunya sudah berkurang. Di beberapa kampung adat seperti Paraingu Kabonduk, telah terjadi peralihan pelaksana pembangunan. Di sini, keterlibatan tukang bangunan dalam proses pembangunan mengganti gotong royong warga. Hal ini sangat membantu pemilik rumah adat yang memiliki kesibukan di luar rumah. Namun demikian, ritual budaya seperti prosesi pemasangan kolom dan atap, penetapan tanggal pelaksanaan tetap dilakukan dengan melibatkan tetua dan warga kampung (secara simbolis). Di kampung adat lain, teknologi berupa transportasi material hanya diperbolehkan sampai batas wilayah tertentu. Proses selanjutnya tetap harus mengikuti adat yang berlaku di tempat tersebut.

\section{KESIMPULAN}

Upaya konservasi untuk menjaga kesinambungan budaya dan kelestarian rumah adat Sumba dapat dilakukan dengan mempertahankan bentuk fisik bangunan. Teknologi berupa material, konstruksi, pelaksanaan, maupun transportasi sangat diperlukan terutama untuk menjembatani kekurangan yang diakibatkan oleh ketersediaan material alam selain untuk penghematan bahan baku, kepraktisan, kemudahan dan kecepatan pelaksanaan. Beragam material selain ijuk dapat digunakan seperti seng, paku, balok kayu, papan, semen, dan beton bertulang. Konstruksi ikatan dengan balok gapit dan paku serta bukaan berupa jendela sebagai jawaban atas keterbatasan bahan dan perlunya cahaya serta udara di dalam rumah. Peralihan pelaksana pembangunan dengan melibatkan tukang bangunan kadang diperlukan tanpa meninggalkan ritual budaya.

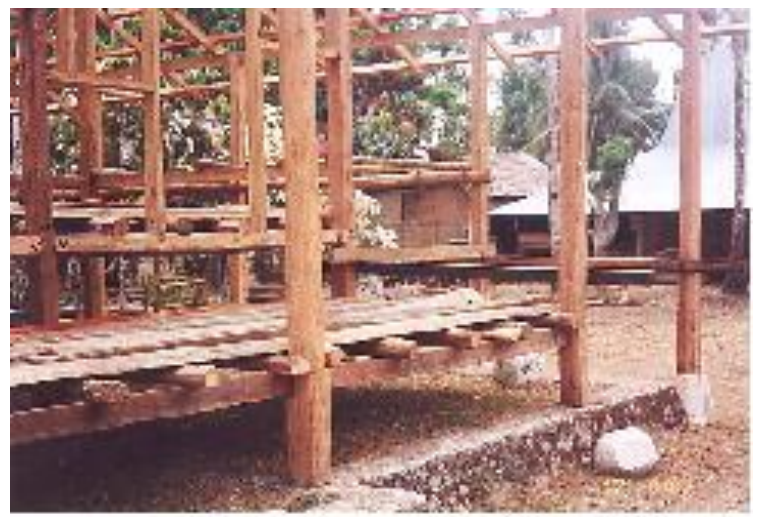

Gambar 4. Renovasi rumah adat dengan pondasi umpak berbahan beton bertulang, balok kayu sebagai rangka atap, kolom penunjang, dan sambungan dengan paku.

\section{REFERENSI}

[1]. Beding, B.L. dan Beding, SIL., 2002, Ringkiknya Sandel Harumnya Cendana, Penerbit Pemda Kabupaten Sumba Timur, NTT. 
[2]. Budihardjo, Eko, 2004, Arsitektur dan Kota di Indonesia, Penerbit Alumni, Bandung.

[3]. Frick, Heinz, 2004, Ilmu Konstruksi Bangunan Bambu, Penerbit Kanisius, Yogyakarta.

[4]. Hoskins, Janet, 1993, The Play of Time, University of California Press, Los Angeles.

[5]. Kapita, Oe.H., 1976, Sumba dalam Jangkauan Jaman, Penerbit BPK Gunung Mulia, Jakarta.

[6]. Machdijar, L.K., Topan, M.A., Winardi, B.L., Winandari, M.I.R., dan Sofian, I., 2007, Jejak Megalitik Arsitektur Tradisional Sumba, Penerbit Graha Ilmu, Yogyakarta.

[7]. Winandari, M.I.R., Machdijar, L.K., Topan, M.A., Winardi, B.L., dan Sofian, I., 2006, Arsitektur Tradisional Sumba, Penerbit Universitas Trisakti, Jakarta. 